\title{
GNAS NP_000507.1:p.Q227L
}

National Cancer Institute

\section{Source}

National Cancer Institute. GNAS NP 000507.1:p.Q227L. NCI Thesaurus. Code C146966.

A change in the amino acid residue at position 227 in the guanine nucleotide-binding protein $\mathrm{G}(\mathrm{s})$ subunit alpha isoforms short protein where glutamine has been replaced by leucine. 